\title{
SECURITIZATION IN POLAND - AN INNOVATIVE SOLUTION IN THE TAX PERSPECTIVE?
}

\section{Krzysztof Biernacki}

Faculty of Economic Sciences, Wrocław University of Economics, Wrocław, Poland

\begin{abstract}
:
Development of international financial markets depends on financial innovations. For those markets, securitization of assets may be regarded as one of such innovations. Since 1997 some securitization programs have been executed in Poland as well. Until now, the number of securitization programs has been growing mainly in the Polish bank sector. In the light of theories on financial innovation, this study is an attempt to answer the question of whether domestic securitization is a new financial instrument. The analysis is provided only in the tax perspective, which significantly shapes the securitization market in Poland.
\end{abstract}

Keywors:

securitization, taxation, innovation.
Correspondence:

Krzysztof Biernacki

e-mail:

krzysztof.biernacki@ue.wroc.pl

\section{INTRODUCTION}

The issue of innovation in the capital markets has been finally encapsulated in a number of scientific theories that seek to elucidate the circumstances of its origination. Since the early 1990s, the Polish market has also followed that general trend, which in this country translates mainly into implementation of the already developed solutions and, if needed, their adjustment to domestic institutions. An example of such operations may comprise securitization issues that have taken place in Poland since 1999. The recent twenty years of development of securitization services in Poland make it legitimate to suggest a hypothesis that securitization of assets may be regarded as a financial innovation. But the tax issue exemplified how the international instruments are adjusted to domestic perspective. In Poland, the tax system favors only one form of asset securitization - bank assets securitization with investment funds; thus raising the question whether this financial instrument is still an innovative solution?

In order to provide an answer to this question, this study presents actual theories on innovation in the financial sector and the taxation of this instrument in Poland. The research methods applied for the purposes of this article include literature analysis regarding the financial innovation theory, analysis of cases related to securitization issue in Poland and application of the legal framework from the tax perspective.

The study consists of two parts. The first of them presents the existing theories of financial innovation with literature review, while the second discusses the taxation of securitization transactions in Poland and it also presents securitization issuances up to now. The article ends with a summary section, which leads to the final conclusion. 


\section{THEORIES ON FINANCIAL INNOVATION -} OUTLINE

The lack of single theory implies that the issue of financial innovations is complex. The difficulties to determine that concept in a clear-cut way also result from the varied development of areas of the international capital market (e.g. the United States and Western Europe ${ }^{1}$ ). The notions that have been reinforced so far may be grouped as follows: demand- oriented group, supply-oriented group, mixed (demand and supply-oriented) group, a group based on the capital market theory as well as the institutional economy theory. ${ }^{2}$ The grouping criterion depends on the structure of elements that impact development of an innovation. Each of those theories attempts to find a specific condition that directly affects the development of a new financial instrument. Individual theories, along with their authors and recognition clues, are presented in Table 1.

Table 1. Theories on financial innovation

\begin{tabular}{ccc}
\hline Theory type & Representative & $\begin{array}{c}\text { Conditions facilitating } \\
\text { development of innovation }\end{array}$ \\
\hline 1. Demand-oriented & $\begin{array}{c}\text { S. I. Greenbaum, } \\
\text { C. F. Haywood }\end{array}$ & $\begin{array}{c}\text { Income and substitution effects } \\
\text { in capital market }\end{array}$ \\
\cline { 2 - 3 } 2. Supply-oriented & W. L. Silber & Competitiveness \\
\cline { 2 - 3 } & W. L. Silber and M. Ben-Horim & Legal restrictions \\
3. Based on capital market theory & C. R. Dunham, & Interest rates and risk \\
\hline 4. Based on institutional economy & J. C. Van Horne & market completeness / cohesion \\
\hline
\end{tabular}

Source: own study based on Hastenpflug W., Das Securitizationsphänomen, Wiesbaden 1991, p. 45.

In the supply-oriented theory, the income and substitution effects in the capital market are construed as a function that interconnects demand for financial instruments with growing income or movements in interest rates, taking account of the available (alternative) products. ${ }^{3}$ Developing those hypotheses, S. I. Greenbaum and C. F. Haywood pointed to a significant correlation between an increasing value of assets subject to investment in capital markets and costs of their diversification. ${ }^{4}$ In relation with the theory by H. M. Markowitz, where a greater portfolio diversification results in risk diminishing, the investors endeavor to generate the highest possible rate of return at the given risk level. At the same time, the costs related to the portfolio management, including portfolio diversification costs, are incurred. Those costs are on increase if the value of the portfolio is growing. According to the theory, the demand for a financial innovation arises when the costs of the portfolio management begin to exceed the gains on those assets.

As opposed to the demand-oriented theory, supply-oriented concepts may be grouped into a few trends, each of

1 Franzen Ch., Finanzinnovation - was ist das? Die Bank No. 1/1988, pp. $18-20$

2 Hastenpflug H., Das Securitizationsphänomen, Wiesbaden 1991, pp. 43-44

3 Gurley J. G., Shaw E. S., Financial Intermediaries and the SavingInvestment Process, Journal of Finance, Vol. 11, 1956, p. 532 which highlights a different aspect of an innovation development. A model by E. J. Kane, also referred to as regulatory dialectic, recognizes innovations as a reply to a legal regulation that limits the freedom of action. The theory is based on the assumption that cyclical changes occur and adjustment of two opposing trends is required: political intervention in the economy, which is manifested in establishing legal regulations, and pursuance of business processes to evade those regulations. The struggle between those drives may be compared with an interaction of visible and invisible forces, where the first one is represented by the actual transactions in the market, and the other mirrors the introduced regulations. ${ }^{5}$ The temporarily achieved equilibrium is thrown off balance due to an action of one of the parties and the whole process starts anew. Such a speculative presentation of the entire change process - to which the theory owes the name "dialectic" - has been confirmed in the course of actual financial market operation. An example may include statutory restrictions, introduced as early as the 1930s in the United

4 Greenbaum S. I., Haywood C. F., Secular Change in the Financial Services Industry, Journal of Money, Credit, and Banking, Vol. 3, No. 2, 1971, p. 573

5 Kane E. J., Impact of Regulation on Economic Behaviour. Accelerating Inflation, Technological Innovation, and the Decreasing Effectiveness of Banking Regulation, Journal of Finance, Vol. 36, No. 2, 1981, p. 358 
States, with respect to determination of the maximum interest rates for deposits. The growing inflation in the 1960s resulted in the opening up of new possibilities of depositing, which enabled evasion of the then existing regulations. ${ }^{6}$

Sequential approach to the innovation process by E. J. Kane is based on a premise of innovation and regulatory lags that arise from the calculation of the costs of innovation. Introduction of a given regulation makes an innovation happen only if the probable profit from the innovation is greater than the cost of such an introduction. The lag may be a consequence of "accumulation" of factors, which will determine profitability of its introduction. If influence of the regulation is immaterial for the increase in the costs of the market operation, then an innovation does not occur immediately. It may happen in the future if the costs of its introduction are reduced. This may be affected by external changes such as higher inflation rate in the already presented example of deposits or technological changes. Then, while the profit remains constant, the costs of implementation may be downsized to such an extent that development of an innovation will turn profitable. If, however, a regulation impacts profitability of the market transaction in a vital way, it may encounter a relatively prompt response in the form of a new financial service aimed at evasion of those unfavorable regulations.

The same may be applied the other way round, where the significance of the innovation is reviewed from the legislator's perspective. In his theory, W. L. Silber deepens the understanding of the restrictions that trigger innovations. In addition to the legal regulations, as external factors, he also takes into account internal restrictions occurring in a given market (e.g. demand for given products), or the ones imposed by the entities themselves (e.g. mutual deposit securities). The source of an innovation's development is sought in two aspects. ${ }^{7}$ The first one involves dropping profits from operations of financial institutions in given markets. As a consequence of external changes, such as decreasing demand for credit, banks are forced to introduce new products or search for new market segments at the expense of the developing security market that provides for immediate financing. The second one involves the costs related to the existing and implemented regulations. Those alterative costs derive from fulfillment of certain conditions, both external (legal regulations) and internal, which require additional expenditures to be incurred in order to track the changes, modifications and to be adjusted accordingly. An innovation arises when the profit from given services is on decrease or the costs of operation under certain regulations are too extensive.

6 Glogowski E., Münch M., Nowe ustugi finansowe, Warszawa 1996, pp. 253-254

7 Silber W. L., Towards a Theory of Financial Innovation, Lexington 1975, pp. 65-66

8 Van Horne J. C., Financial Innovations and Excess, Journal of Finance, Vol. 41/1985, p. 621
The theory by J. C. Van Horne is based on two assumptions: reaching for operating effectiveness of capital markets and making them total, more complete. ${ }^{8}$ The notion of operating effectiveness assumes that the costs of capital flow between the entities should be as low as possible. An innovation provides, therefore, for reduction in paid commissions, interest etc., and enables more efficient and immediate allocation of the existing funds. Totality does not imply here any struggle for total (weighty) market effectiveness in the meaning of asset valuation models ${ }^{9}$, but it rather involves the occurrence of such financial instruments that are in correspondence with the given point in time and the specific economic situation. It is, hence, possible to complete a transaction with the use of securities or their combination, to provide for inclusion of any future event. An innovation is an instrument that is introduced to bridge the existing gap, as there has been no possibility so far to conduct a transaction in view of a given period or with respect to a given event. An example of such an innovation may be the creation of a product that will secure the transaction in the forex market for a period longer than is possible with the existing instruments.

According to that theory, a financial innovation would not occur in a market of complete effectiveness, where all information was reflected in the price of assets. As markets are not effective in the above sense, there are incentives that may trigger development of innovations. C. Van Horne listed variability of economic ratios (inflation, interest rate), impact of legal regulations as well as technical and social progress among such incentives.

Functioning of social structures defined as institutions substantiates development of an innovation, according to the theory by G. Dufey and I. H. Giddy. Within the frame of the institutional economy, in order to function properly, the society is required to minimize the so-called transaction costs that constitute a material aspect of the agreements made. ${ }^{10}$ If no relevant protection of competition and property rights (incl. intellectual property rights) exists, the incentives to foster innovation are on decrease. ${ }^{11} \mathrm{~A}$ paradox in this theory may be the fact that the actual capital market development since the 1980s has removed the necessity to protect patents for the introduced innovations, and their imitations became the drivers of the global financial market development.

The authors of this theory classified the financial innovations into two types. The first one is called aggressive innovation, which is the result of a search made by the companies that specialize in generation of products of this kind. Potential buyers will be more willing to acquire new instruments

9 Czekaj J., Woś M., Żarnowski J., Efektywność giełdowego rynku akcji w Polsce, Warszawa 2001, p. 32

10 Williamson O. E., Ekonomiczne instytucje kapitalizmu, Warszawa 1998, p. 390

11 Dufey G., Giddy I. H., The Evolution of Instruments and Techniques in International Financial Market, Société Universitaire Européenne de Recherches Financiéres 1981, p. 2 
from known and reputable companies, as that involves less risk. On the other hand, such solutions are more expensive than the imitations to come in the future, as their price includes an additional cost related to both research on the innovation as well as a possible risk to fall in disrepute in case a faulty solution is introduced. We may even speak about a peculiar monopoly on introducing innovations, which is held by well-known financial institutions. The second group comprises the so-called defensive innovations that address the changes in regulatory laws, or asset interest rates and risk. The notion of this kind refers explicitly to earlier theories by E. J. Kane and W. L. Silber (legal regulations) as well as by C. R. Dunham (interest rates and risk).

\section{TAXATION OF ASSET SECURITIZATION IN POLAND}

Until the late June 2004, securitization was subject to general taxation rules. As of July $1^{\text {st }}$, its legal status changed as a result of the Investment Fund $\mathrm{Act}^{12}$ that took effect. By virtue of that amendment, the legislator has established a special type of an investment fund, the so-called securitization fund (art. 183 of the IFA), which, being another form of a closed-end investment fund, issues certificates to raise financial capital in order to acquire debt receivables. At the same time, this Act, in the part that amends other statutes, has brought about a change in the Banking Law ${ }^{13}$ (Art. 312 of the IFA) as well as in the Corporate Income Tax Act ${ }^{14}$ (Art. 303 of the IFA) by way of determining the conditions binding for taxation of bank debt receivables under securitization.

At present, the tax regulations distinguish among at least three groups of securitization transactions, which bring about different tax consequences. The first group involves securitization of bank debt receivables with an investment fund. The second one includes securitization of other debt receivables with the fund, whereas the third group refers to securitization debt receivables, where the SPV's function is fulfilled by an entity other than an investment fund.

As a result of the said amendment, regulations of the CIT Act legally exempted from taxation, first of all, investment funds, which is also applicable to securitization funds (Art. 6 item 1 sub-item 10 of the CIT Act). Such a regulation defines the international standards applied to SPV vehicles, which should be exempted from the tax. ${ }^{15}$ At the same time, the bank selling the debt receivables does not recognize as revenues the debt receivables due from credits (loans), transferred to a securitization fund or an investment fund association that established them, up to their outstanding amount (Art. 12 item 4 sub-item 15 of the CIT Act). Simultaneously, a loss

12 Investment Fund Act of 27 May 2004, Journal of Laws No. 146 item 1546, as amended, hereinafter: the IFA

13 Banking Law Act of 29 August 1997, Journal of Laws No. 140 item 939, as amended, hereinafter: the Banking Law. from the sale of debt receivables due from credits (loans) to a securitization fund or an investment fund association that established them, the loss being a difference between the amount earned from that sale and the value of the debt receivables due from credits (loans) and matching the value of a provision already made for that part of debt receivables, as recognized under tax-deductible (revenue earning) costs, is the tax-deductible cost for the bank (art. 15 item $1 \mathrm{~h}$ subitem 2 of the CIT Act). As a matter of fact, this solution is in line with the general rule that the loss from sale of debt receivables is a tax-deductible cost if at the moment of its incurrence, it was recognized as taxable revenue (a contrario art. 16 item 1 sub-item 39 of the CIT Act), although the credits granted by banks are not classified as revenues. Moreover, pursuant to art. 16 item 1 sub-item 10 lettere of the CIT Act, expenses attributable to transfer of financial assets from repayment of credits (loans) subject to debt receivable securitization, by a bank to a securitization fund or an investment fund association that established them are not considered tax-deductible costs. To sum up, it may be concluded that from the income tax perspective, bank asset securitization with a securitization fund is not only neutral, but also brings about additional benefits such as possibility to recognize as tax-deductible costs the loss from the sale of debt receivables, which have not been disclosed as revenues earlier.

Introduction of specific taxation rules regarding securitization of bank assets has led to this market being dominated primarily by issuances of this type. Since 2006 , virtually only banks or bank-owned financial entities (leasing companies) have made securitization issues. This is shown in Table 2.

Tax regulations do not provide for any specific tax and legal solutions with respect to securitization of other debt receivables, except for the aforementioned legal exemption of the securitization fund from the income tax obligation. This means that, already in this case, it is possible to find the described discrepancies in treatment of the sale of debt receivables with sales taxes. Moreover, such a transaction is not so favorable when it comes to the income tax. A loss from disposal of debt receivables other than bank assets is, as a matter of fact, a tax-deductible cost provided that the already accrued receivables were previously classified as taxable revenues (art. 16 item 1 sub-item 39 of the CIT Act). In practice, if the total costs of a transaction are increased by a tax on civil law transactions and added to the high cost of establishing and running a securitization fund, any potential participant may feel effectively deterred from completing such a transaction.

The first securitization of debt receivables without a securitization fund in Poland was carried out in the late nineties. The scarcity of such transactions until now is a result of i.a.

14 Corporate Income Tax Act of 15 February 1992, Journal of Laws No. 21 item 86, as amended, hereinafter: the CIT Act.

15 Kendall L. T., Fishman M. J., A Primer on Securitization, The MIT Press, Cambridge Massachusetts 1996, p. 3 
an imminent tax risk, which is posed by both an increase in the transaction cost as well as unclarity of tax treatment of individual parts of that transaction. The already mentioned obligation to tax assignment of bank debt receivables with the civil law transaction tax applies as well if other debt receivables are sold. As a consequence, the tax at the rate of $1 \%$ of the assignment value significantly affects the final profitability of such a transaction.

In the income tax area, the greatest difficulty is posed by coordination over time of the receipts and expenses on both the initiator's and the SPV's side, so as to have the transactions that generate the taxable revenues and tax-deductible costs concluded in the same settlement period. Moreover, in such securitization transactions, the SPV is most frequently a limited liability company, which is treated as a taxpayer subject to all the duties to keep records and make settlements. Although the costs of establishing such a company are lower than those of an investment fund, the poor interest in this form of securitization may be evidenced by the fact that securitization of bank debt receivables does not account for such a form. Regulations of the Banking Law provide for the possibility to sell bank debt receivables by an issuing entity (incorporated company) other than a securitization fund (Art. 92a item 3 of the Banking Act).

Table 2. Asset securitization in Poland - volumes and categories of assets

\begin{tabular}{|c|c|c|c|c|}
\hline L.p. & Originator & Asset category & Volume & Year \\
\hline 1 & $\begin{array}{l}\text { Utrica Zaopatrzenie } \\
\text { Farmaceutyczne SA }\end{array}$ & $\begin{array}{c}\mathrm{Se} \neg \text { curitization of receivables from } \\
\text { sales of pharmaceuticals }\end{array}$ & PLN 50 million & 1999 \\
\hline 2. & Pekao Leasing Sp. z o.o. & Leasing receivables & PLN 4,3 million & 2000 \\
\hline 3. & Pharmag SA & Trade receivables, & PLN 100 million & 2001 \\
\hline 4. & Dominet Bank SA & Car loans & PLN 600 million & 2006 \\
\hline \multirow{4}{*}{5.} & \multirow{4}{*}{ Raiffeisen-Leasing Polska SA } & \multirow{4}{*}{ Leasing receivables } & PLN 640 million & 2006 \\
\hline & & & PLN 360 million & 2008 \\
\hline & & & PLN 950 million & 2014 \\
\hline & & & PLN 525 million & 2015 \\
\hline 6. & Raif $\neg$ feisen Bank Polska SA & SME loans & EUR 270 million & 2006 \\
\hline 7. & Millennium Leasing Sp. z o.o. & Leasing receivables & PLN 850 million & 2007 \\
\hline \multirow{2}{*}{8.} & \multirow{2}{*}{ Getin Noble Bank SA } & Car loans & $\begin{array}{l}\text { PLN } 1000 \\
\text { million }\end{array}$ & 2012 \\
\hline & & Leasing receivables & $\begin{array}{l}\text { PLN } 1900 \\
\text { million }\end{array}$ & 2015 \\
\hline \multirow{2}{*}{9.} & \multirow{2}{*}{ Santander Consumer Bank SA } & Retail and car loans & $\begin{array}{l}\text { PLN } 1751 \\
\text { million }\end{array}$ & 2014 \\
\hline & & Installment loans & $\begin{array}{l}\text { PLN } 1260 \\
\text { million }\end{array}$ & 2015 \\
\hline
\end{tabular}

Source: Buszko M., Krupa D., Discussion about developing securitization in Poland with participation of securitization investment funds, Economics and Law, Vol. 15, Issue 3, p. 285

\section{SUMMARY}

Considering the above-presented theories of innovation, some conclusions may be presented to indicate the trends for developing such innovations as securitization in Poland

a) innovations arise in those branches of the economy where no clear-cut rules of operation of public and private institutions exist;

b) an essential reason for developing an innovation is an attempt to downsize the statutory costs of transaction, as attributed to assertion of the ownership title; c) entities that have the base to introduce innovations (banks) follow this path exclusively upon implementation of individual tax solutions, which enable them to ease the burdens under the public law.

Amendment of tax regulations with respect to just one group of initiators, that is banks in Poland, shows how farreaching the final influence of tax-related changes on profitability of the transaction may be. Only after certain regulations became more specific and combined with special tax solutions, was it possible to develop that financial instrument in practice. As a result of limiting that instrument exclusively 
to bank assets, the securitization market based on other assets or on transactions concluded with an SPV being an entity other than investment funds, as a matter of fact, is marginalized. It means that the regulation amendments in the E. J. Kane's theory cannot explain securitization in Poland as an innovative solution. Finally the hypothesis proposed in the introduction herein has not been proven. After the introduction of special taxation rules for bank securitization, the development of securitization issues in Poland ceased to be an innovation within the meaning of the above-specified theories and has become a financial instrument created by the legislature.

\section{LITERATURE}

M. Buszko, D. Krupa, Discussion about developing securitisation in Poland with participation of securitisation investment funds, Economics And Law, Vol. 15, Issue 3, p. 285

Czekaj J., Woś M., Żarnowski J., Efektywność giełdowego rynku akcji w Polsce, Warszawa 2001, p. 32.

Dufey G., Giddy I. H., The Evolution of Instruments and Techniques in International Financial Market, Société Universitaire Européenne de Recherches Financiéres 1981, p. 2.
Franzen Ch., Finanzinnovation - was ist das ?, Die Bank No. 1/1988, pp. 18-20.

Glogowski E., Münch M., Nowe ustugi finansowe, Warszawa 1996, pp. 253-254.

Greenbaum S. I., Haywood C. F., Secular Change in the Financial Services Industry, Journal of Money, Credit, and Banking, Vol. 3, No. 2, 1971, p. 573.

Gurley J. G., Shaw E. S., Financial Intermediaries and the SavingInvestment Process, Journal of Finance, Vol. 11, 1956, p. 532.

Hastenpflug H., Das Securitizationsphänomen, Wiesbaden 1991, pp. 43-44.

Kane E. J., Impact of Regulation on Economic Behaviour. Accelerating Inflation, Technological Innovation, and the Decreasing Effectiveness of Banking Regulation, Journal of Finance, Vol. 36, No. 2, 1981, p. 358.

Kendall L. T., Fishman M. J., A Primer on Securitization, The MIT Press, Cambridge Massachusetts 1996, p. 3.

Silber W. L., Towards a Theory of Financial Innovation, Lexington 1975, pp. 65-66.

Van Horne J. C., Financial Innovations and Excess, Journal of Finance, Vol. 41/1985, p. 621.

Williamson O. E., Ekonomiczne instytucje kapitalizmu, Warszawa 1998, p. 390 